PALEO

Revue d'archéologie préhistorique

27 | 2016

Varia

\title{
The Solutrean bone industry from Rochefort Cave (Saint-Pierre-sur-Erve, Mayenne, France)
}

\section{Malvina Baumann and Stéphan Hinguant}

\section{(2) OpenEdition}

1 Journals

\section{Electronic version}

URL: http://journals.openedition.org/paleo/3232

DOI: 10.4000/paleo.3232

ISSN: 2101-0420

\section{Publisher}

SAMRA

\section{Printed version}

Date of publication: 30 December 2016

Number of pages: $43-63$

ISSN: 1145-3370

\section{Electronic reference}

Malvina Baumann and Stéphan Hinguant, « The Solutrean bone industry from Rochefort Cave (SaintPierre-sur-Erve, Mayenne, France)»,PALEO [Online], 27 | 2016, Online since 01 June 2018, connection on 07 July 2020. URL : http://journals.openedition.org/paleo/3232 ; DOI : https://doi.org/10.4000/ paleo.3232

This text was automatically generated on 7 July 2020 .

\section{cc) (i) $\odot$}

PALEO est mis à disposition selon les termes de la licence Creative Commons Attribution - Pas d'Utilisation Commerciale - Pas de Modification 4.0 International. 


\title{
The Solutrean bone industry from Rochefort Cave (Saint-Pierre-sur- Erve, Mayenne, France)
}

\author{
Malvina Baumann and Stéphan Hinguant
}

\section{Introduction}

1 The site of Rochefort cave is one of the fifty French Solutrean sites that have yielded an industry on hard animal matter. In this context, it has two major interests. First, it is one of the few sites alongside Combe-Saunière (Sarliac-sur-l'Isle, Dordogne; Geneste 1978-88), Cuzoul-de-Vers (Vers, Lot; Clottes and Giraud 1982 -86), Les Jean-Blancs (Bourniquel, Dordogne; Cleyet-Merle 1985-88), Les Peyrugues (Orniac, Lot; Allard 1985-88) and Petit-Cloup-Barrat (Cabrerets, Lot; Castel since 2004) that have been excavated recently (Hinguant and Colleter 2005-2010). Today, the data available on Solutrean bone industry come mostly from excavations carried out between the end of the $19^{\text {th }}$ and the beginning of the $20^{\text {th }}$ century, that is to say from collections obtained by selective collecting, often decontextualized and generally altered both physically and in their composition (Baumann 2014). The Rochefort corpus thus escapes these traditional biases and constitutes a homogeneous and significant working basis.

2 Secondly, Rochefort is one of the most northerly sites of the Solutrean territory (fig. 1; Hinguant et al. 2013). The chronological and typological frameworks that structure the period are still largely based on the sites of southwestern France, between the Charente, Dordogne and Lot regions. The excavations carried out outside this geographical and historical heart, as at the sites of Vale Comprido (Portugal; Zilhão and Aubry 1995), Parpalló (Spain; Tiffagom et al. 2007), Marseillon (Landes; Teyssandier et al.; Renard 2008), Les Maîtreaux (Indre-et-Loire; Aubry et al. 2004) and Les Bossats (Seine-et-Marne; Bodu et al. 2014) are gradually completing and modifying the frameworks, notably by highlighting regional specificities. Rochefort's elements of 
bone industry are thus opening the way to new inter-regional comparisons, on a still little documented aspect of material culture.

Figure 1 - Location of Rochefort cave in the Pleniglacial context of the Middle Solutrean with «laurel leafs».

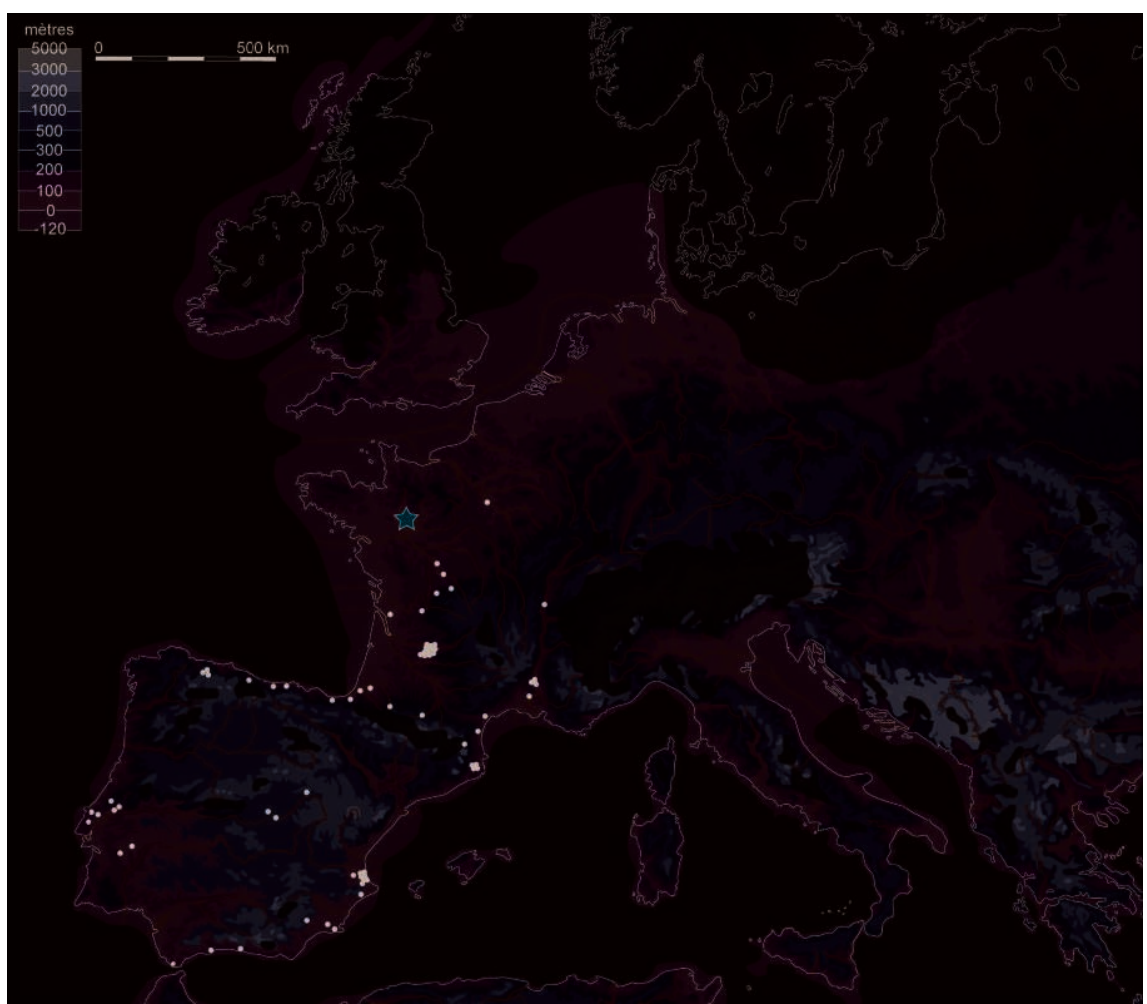

(Map by R. Colleter)

3 The study presented here focuses exclusively on the toolkit. We have not taken into account the ornaments and "engraved" artefacts included in the corpus of more specifically symbolic objects (Hinguant et al. 2012).

\section{1 - Presentation of the site}

4 The small limestone block of Saulges, in which a karst has formed, is an exception for the western part of France as the physicochemical context of the site is particularly favorable for the preservation of bone remains. In the 20 or so caves currently known within this geographical entity, Quaternary fossils have been collected since the $19^{\text {th }}$ century and these discoveries have resulted in more or less destructive excavations from the 1870s. But the archaeological potential remains strong and in Rochefort cave, the resumption of the excavations by a research program of the UMR 6566 led to (re)discover this Solutrean site.

5 Rochefort Cave, as visited by the Paleolithic human groups, consists of a $150 \mathrm{~m}^{2}$ large triangular hall at the end of a long straight corridor behind the entrance porch. Its vault is sloping according to a stratification joint of the rock. Its volume is large enough for a living space in spite of the almost total darkness. At the southern end, where current excavations took place, the outlet of a karstic chimney, now blocked, is the source for most of the sedimentary deposits of the filling. 
In this part of the cave, the Solutrean deposits make the lower $50-60 \mathrm{~cm}$ of a $1.5 \mathrm{~m}$ high stratigraphy. These deposits are formed of a stony mass composed of calcareous clasts of medium to large size, resulting from the erosion of the chimney, sealed in a claysandy matrix. The post-depositional action of freezing is marked by the straightening of blocks and small plaques, but the vertical deformations remain few in this slightly sloping assemblage, subdivided into sublayers (4.1 to 4.7 ). The majority of Solutrean archaeological objects are located in the heart of Unit 4, in Layers 4.3 and 4.4. Without denying the existence of a few intrusive bone pieces from the layer overlying Unit 4 , attributed to the late glacial, the corpus of objects collected to date shows the true chronostratigraphical homogeneity of the assemblage, confirmed by a series of radiocarbon dating placing the occupation(s) around 19,500 BP (Hinguant and Biard 2013 - p. 242). Moreover, if the usual taphonomic damage encountered in the karstic environment are present in Rochefort cave (traces of roots, corrosion, dissolution, concretions, etc.), there is a smaller damaging of the bone remains by small carnivores and the absence of hyena-related activity (Bemilli and Hinguant 2014).

7 The material identified in the cave can be connected to the old middle Solutrean with "laurel leaf", that is to say to the upper Solutrean but without possible confusion with the upper Solutrean with shouldered points, taking into account the total absence of this type of artefact in the sites of the Erve valley to date. The characterization of a singular lithic assemblage, with the use of varied raw materials, including a lustrous sandstone with remarkable clastic qualities, is not the least of the originalities of the site. This lithic corpus, made of about 2,000 objects up to date, contains nearly 60 leafshaped pieces ("laurel leaf" and "willow leaf") as well as numerous waste coming from the final shaping or re-sharpening phases, showing that these stages of the chaine opératoire took place inside the cave. The relative small size of most of these "leaves" can be noted, especially in comparison with those found in the other sites in the valley (porch of the Derouine cave, Margot cave), and the question arises as to their function as knife or projectile insets (Biard and Hinguant 2015).

8 The faunal spectrum, determined from about 5,500 artefacts and osseous fragments, is typically representative of a cold and dry environment corresponding to the conditions of the Last Glacial Maximum (LGM, OIS 2) with a domination of the reindeer (Rangifer tarandus) and the horse (Equus ferus, Equus hydruntinus, Equus sp.). Large herbivores also include, to a lesser extent, the Alpine ibex (Capra ibex). The mammoth (Mammuthus primigenius) and the woolly rhinoceros (Coelodonta antiquitatis) are not excluded, although their remains are rare. Carnivores are represented by the wolf (Canis lupus), the polar fox (Alopex lagopus), the brown bear (Ursus arctos, Ursus sp.) and the lynx (Lynx $s p$.) and by a mesofauna including the steppe polecat (Mustela eversmanii), the marten (Martes) and the wild cat (Felis silvestris). Finally, the microfauna, counting over 7,000 remains, is characterized by seven species of rodents, the remains of which originate from predatory activities (birds of prey, foxes, polecats), also reflecting the rigorous climate environment of the LGM, although moderated by several wetland species (Hanquet et al., 2016).

\section{2 - The material}

The assemblage of osseous artefacts includes about one hundred elements of industry. Confirming the preliminary examinations carried out by J.-M. Pétillon and C. Bemilli 
for the excavation reports and a first experiment carried out by M. Biard (Bemilli and Hinguant $2014-$ p. 317 and fig.11), our study shows that it is mainly a little processed toolkit on bone, intended for lithic knapping, including for the shaping of leaf-shaped pieces, and waste from reindeer antler processing (tabl.1).

Table 1 - Number and distribution of bone and antler artefacts from Rochefort cave.

\begin{tabular}{|c|c|c|c|c|}
\hline Matière première & Catégorie & Type & $\mathrm{Nb}$. & Total \\
\hline \multirow{5}{*}{ Os } & \multirow{5}{*}{ Outillage } & Retouchoirs & 26 & \multirow{5}{*}{52} \\
\hline & & Compresseurs & 19 & \\
\hline & & Epingles & 2 & \\
\hline & & Poinçons & 3 & \\
\hline & & Éclats retouchés & 2 & \\
\hline \multirow{5}{*}{ Bois de cervidé } & \multirow{3}{*}{$\begin{array}{l}\text { Restes de } \\
\text { fabrication }\end{array}$} & Déchets & 25 & \multirow{3}{*}{42} \\
\hline & & $\begin{array}{l}\text { Supports et fragments } \\
\text { associés }\end{array}$ & 15 & \\
\hline & & Esquilles de percussion & 2 & \\
\hline & \multirow{2}{*}{ Outillage } & Outils percutés & 3 & \multirow{2}{*}{4} \\
\hline & & Pointe indéterminée & 1 & \\
\hline
\end{tabular}

10 The provisional mapping of these objects on the current excavation area shows a sparse distribution of the remains. The observed densities are similar to that of the whole of the material. Only reindeer antler processing wastes show a particular concentration in the southeastern part, which could correspond to a specific rejection zone. Note also that the awls were found at the level of the hearth emptying and the intermediary tools on antler at the back of the shelter (fig. 2).

11 The proposed count is to be considered as a minimum for two reasons. The first one is related to the state of preservation. From the perspective of a technological study, the objects can be considered poorly preserved. Although post-depositional fragmentation and recent breaks are limited (around 35\%) and do not prevent apprehending the overall shape of the object, the fissuring (90\%), desquamation or disintegration ( $25 \%)$ and dissolution $(20 \%)$ rates, as well as deposits of extremely hard limestone concretions (65\%), make surfaces difficult to read. The combination of these alterations sometimes leads to a total loss of the original surface. The antler pieces are more affected than the bone elements. Their identification therefore relies more on a particular morphology than on the traces relating to their manufacture or their use.

The second difficulty is related to the structure of the Solutrean bone industry. For this period, the majority of the toolkit consists of little processed elements resulting from blank production by splitting (Baumann 2014). Although archaeological and experimental reference sources are increasing for categories of tools such as 
retouchers on diaphysis fragments (Armand and Delagnes 1998; Patou-Mathis et al. 2002; Castel et al. 2003; Tartar 2012a; Mallye et al. 2012; Romandini et al. 2014; Abrams et al. 2014; Schwab 2014), those available for pressure flakers or wastes from the splitting up of antler are being created (Rigaud 2004; Pétillon and Averbouh 2012; Pétillon and Ducasse 2012; Baumann and Maury 2013; Rémy 2013; Baumann 2014; Borao Álvarez et al. 2016). More than twenty objects have been put aside because they cannot be clearly attributed to a category of objects or to a processing stage of the material.

\section{3 - Bone}

Fifty-two objects were made from long bones (fig. 3, A) of medium and large mammals (figure 3, B), mostly metapodials, tibias and equine and cervid femurs. The taxonomically and anatomically determined blanks make it possible to consider that the used bones come from the carcasses of animals hunted and consumed on the site (Bemilli and Hinguant 2014).

Figure 2 - Spatial distribution of the bone industry from the Solutrean layers of Rochefort cave.

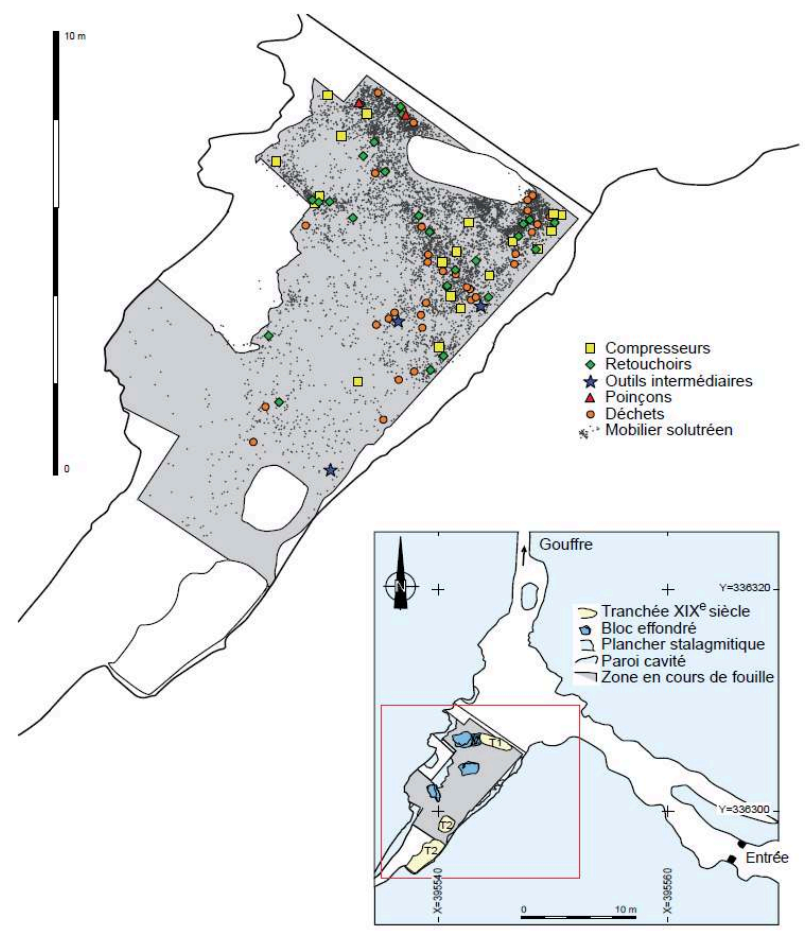

(CAD by R. Colleter) 
Figure 3 - Relative ratio of the anatomical parts used for making bone tools.

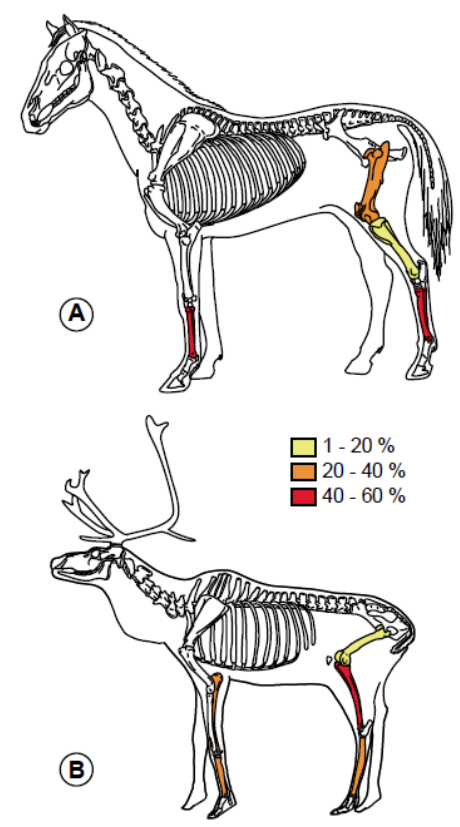

A - from horses : B - from deers (metacarpal and metatarsal bones are not distinguished, so the mentioned rates are for all metapods)

Drawings ( A Archéozoo.org

\section{1 - The retouchers ( 26 pieces)}

The identification of retouchers, which are small hammers for retouching, rests above all on the recognition of their use traces in the shape of impressions resulting from repeated contact with a lithic cutting edge. From the end of the $19^{\text {th }}$ century (Daleau 1883; Henri-Martin 1906) and until recently (Mallye et al. 2012; Jéquier et al. 2012; Abrams et al. 2014; Romandini et al. 2014).), retouchers have been the subject of numerous studies, being the main representatives of bone industry in the Middle Paleolithic assemblages. Two use methods have been put forward for these objects: as a hammer for retouching and as a support for cutting work. Today, the most commonly accepted hypothesis of use is that of a hammer for the retouching of lithic cutting edges. In the Upper Paleolithic, the greater variability in the orientation of use marks and in the quality of the supports makes it possible to consider an evolution in their operation mode (Chase 1990; Schwab 2002; Leroy-Prost 2002; Castel 2003; Tartar 2009, 2012a). At present, there is nothing to distinguish Solutrean retouchers from those of other chronocultures.

\subsection{1 - Raw material and morphometry}

15 Twenty-five specimens are diaphysis fragments (fig. 4), one object is on a ulna. Diaphysis fragments are always longer than broad and the active surface is slightly convex. If the retouchers are used in percussion, the variability of their dimensions and 
therefore of their masses, determine the diversity of the types of operations that they allow. Despite the various taxonomic and anatomical origins of the used bones (metapodials, tibias and cervid and equid femurs), the dimensions are relatively homogeneous, with lengths predominantly between $6 \mathrm{~cm}$ and $8 \mathrm{~cm}$, widths ranging from $2 \mathrm{~cm}$ to $2.4 \mathrm{~cm}$ and thicknesses of $0.3 \mathrm{~cm}-0.4 \mathrm{~cm}$. The retouchers of the corpus are therefore probably intended for the same set of operations.

\subsection{2 - Manufacturing}

16 The blanks are obtained by direct percussion splitting. The use of this debitage method is shown by the presence of impact points and fracture edges located on the sides of the tool. On several specimens, the impact points and the associated notches are diametrically opposed, indicating a percussion on anvil. The shape of the impact points and the percussion notches refers to the use of hammers and anvils with relatively punctiform and irregular active surfaces (fig. 5, A; Turner 1983; Blumenschine 1996; Pickering and Engeland 2006; Galan et al. 2009). Since the register of techniques used is similar to that of a fracturing of bones for food purposes, it is not possible, in the present state of knowledge on the site, to determine whether the blanks of the retouchers are derived from a specific manufacturing chain, whether they are integrated with butchery operations or whether they are the result of an opportunistic recovery among the food waste. A comparison of industry and fauna assemblages remains to be done, even if the corpus of retouchers is statistically little representative.

\subsection{3 - Use}

To the corpus of the 26 simple retouchers are added 9 retouchers on pressure flakers (see below). On these 35 tools, the areas with marks resulting from use are predominantly unique, of low intensity with traces oriented transversely to the main axis of the object (fig. 5, B and C). This configuration reveals both a short use of the retoucher and a relative standardization of the operations it was used for. It should be noted that retouchers from old excavations, with multiple areas forming depressions (fig. 5, D), evoke on the contrary a thorough use of tools. The pressure flakers used as retouchers form a rather heterogeneous corpus. 
Figure 4 - Retouchers from Rochefort cave.

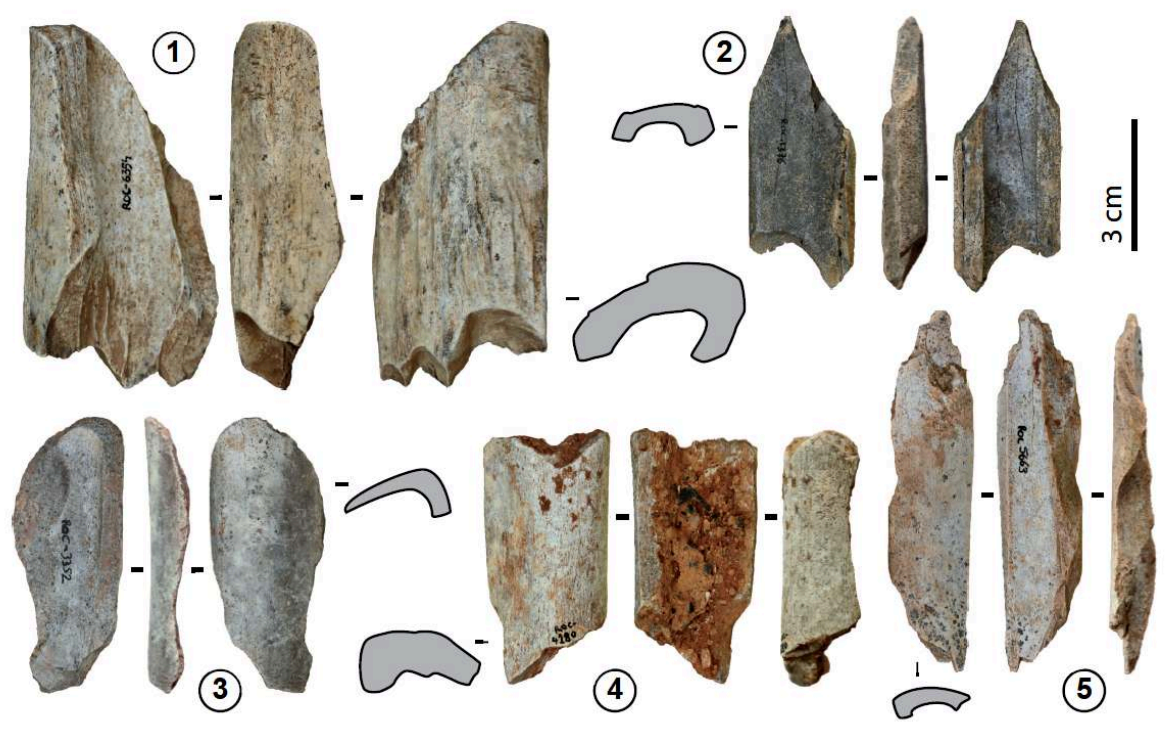

$1-n^{\circ} 6354$ (layer 4.4) ; $2-n^{\circ} 1376$ (I. 4.2) ; 3- $n^{\circ} 3352$ (I. 4.3) ; $4-n^{\circ} 4180$ (I. 4.4) ; $5-n^{\circ} 5663$ (I.
4.4).
(Photos and CAD by M. Baumann)

\section{2 - Pressure flakers (19 pieces)}

Pressure flakers, tools for retouching by pressure, have a relatively wide chronological and geographical distribution in contexts as different as the South-African Middle Paleolithic (D'Errico et al. 2012) and the Swiss Neolithic (Camps-Fabrer and Ramseyer 1992; Maigrot 2003). Because of their frequency and because they are linked to the shaping of leaf-shaped lithic points, pressure flakers are the most characteristic tools of the Solutrean bone industry, at least for the middle and recent phases of the period (Cheynier 1949; Baumann and Peschaux 2014; Baumann 2014). Their presence in the Rochefort site could go hand in hand with that of small "laurel leaves", "willow leaves" and pressure-retouched blades and constitutes an additional clue showing for the latter that the final stages of the shaping were carried out in situ (Biard and Hinguant 2015).

\subsection{1 - Raw material}

The blanks for the pressure flakers are mostly made on metapodials and tibias of medium and large mammals, reindeer and equid for the determinate elements. The fact that all of Rochefort's pressure flakers are on bone constitutes a remarkable feature, the vast majority of the Solutrean pressure flakers known to date being on large-size antler (Baumann 2014). This observation may nevertheless be qualified. As the Solutrean osseous material mostly comes from ancient excavations, the little processed tools on bone, for lack of being identified and collected, are often lacking from the collections. However, the total absence of antler specimens in Rochefort could result from the influence of several parameters: that of the lithic raw material used for the manufacture of the leaf-shaped points and that of the availability of hard animal matter resources. In the lithic corpus, more than 1,000 pieces out of 2000, including 
"laurel leaves", are made from lustrous sandstone, a material whose knapping qualities, although good, differ from those of the flint and gritstone also present and could require the use of a particular type of pressure flaker. Bone does not have the same elastic deformation capabilities as antler. More rigid, it cannot, for example, accumulate as much strength as antler but it can concentrate and redirect it more directly. The continuation of the experiments would allow us to better understand the advantages and disadvantages of a combination of glossy sandstone / bone pressure flaker. The absence of antler pressure flakers could also be due to a lack of supply of adult male antler (see section 3.2.1). In the studied corpus, the antlers from juveniles, young males or females predominate. If adult male antler has been brought to the site, it may not have been collected locally and/or has been kept for the manufacture of another category of tool (see section 4.2 below, intermediary tools).

Figure 5 - Manufacturing and use wear traces on retouchers.

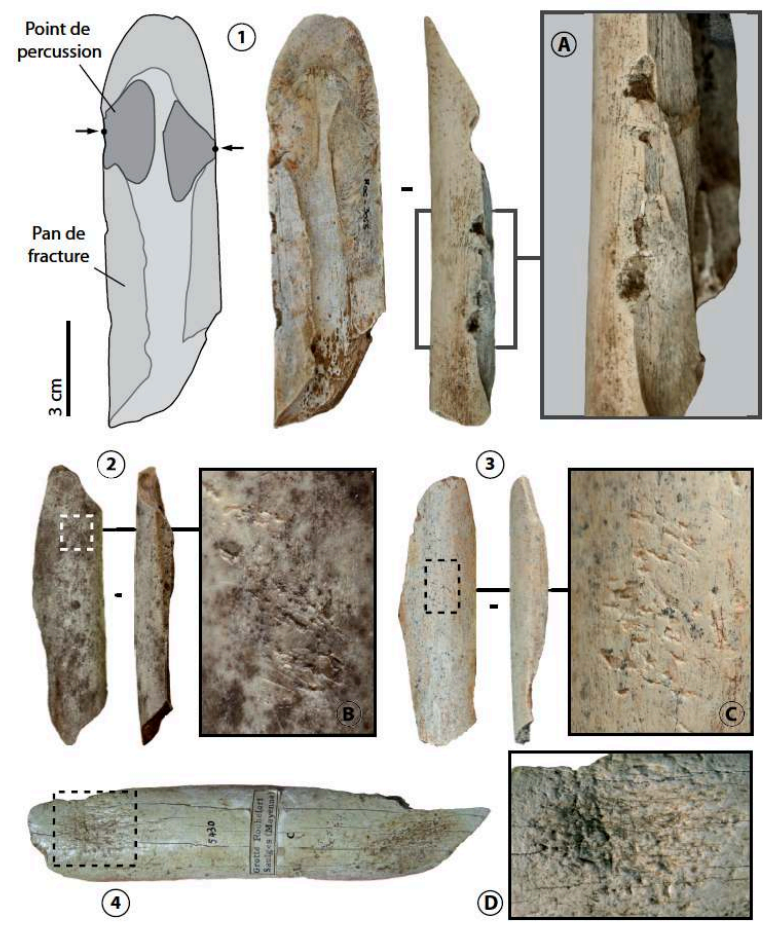

A - impact point ; $B$ - impressions on simple tool ; $C$ - impressions on pressure flaker ; $1-n^{\circ} 3025$ (layer 4.4); $2-n^{\circ} 3003$ (I. 4.3); 2 - n² 2571 (I. 4.3); $3-n^{\circ}$ inv. 5430 (MAN, coll. R. Daniel)

(Photos and CAD by M. Baumann)

\subsection{2 - Morphometry}

The corpus includes 19 pieces, 15 of which are probably whole. For the latter, we cannot say whether the fractures, on fresh materials (Baumann and Maury 2013), are due to the debitage of the blanks or result from use. The profiles of the objects are rectilinear and the proximal part is generally wider than the distal part. The concavoconvex sections conform to the natural shape of the bone (fig. 6). The lengths of the whole objects are mainly between $6 \mathrm{~cm}$ and $10 \mathrm{~cm}$. These sizes are in the low range of lengths generally encountered for whole Solutrean pressure flakers, which can range 
from about $5 \mathrm{~cm}$ to $20 \mathrm{~cm}$ (Baumann, 2014). The widths are more heterogeneous and the maximum thicknesses, mostly between $0.5 \mathrm{~cm}$ and $0.8 \mathrm{~cm}$, directly reflect the thickness of the used bone compact tissue. In spite of rather short lengths, the lack of standardization in the widths and the absence of working such as adhesion striations, make us consider the hypothesis of using the pressure flakers in the hand without hafting (Baumann 2014).

Figure 6 - Pressure flaker from Rochefort cave.

(1)

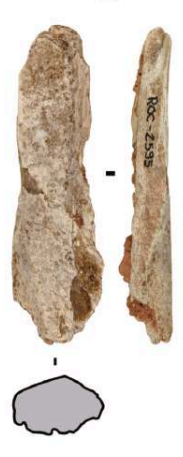

$3 \mathrm{~cm}$
(2)

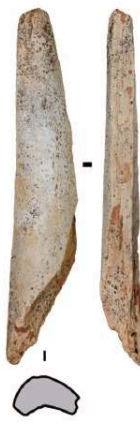

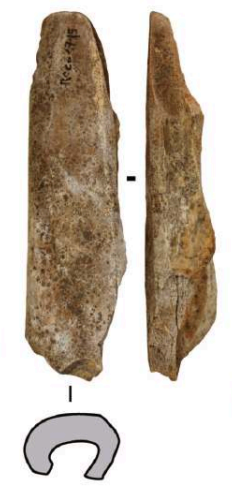

(3)
(4)

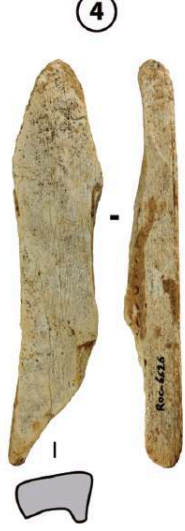

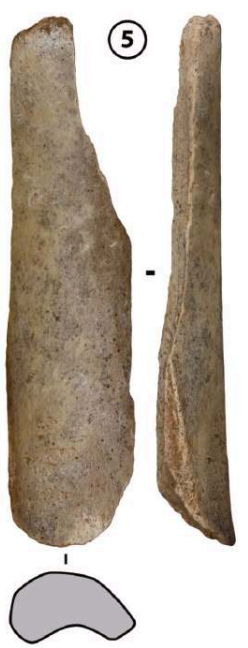

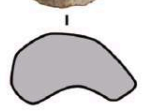

$1-n^{\circ} 2595$ (couche 4.3) ; $2-n^{\circ} 3208$ (c. 4.3) ; $3-n^{\circ} 4715$ (c. 4.4) ; $4-n^{\circ} 6626$ (c. 4.4$) ; 5-n^{\circ} 6209$ (c. 4.4).

(Photos and CAD by M. Baumann)

\subsection{3 - Manufacturing}

The pressure flakers of the site are on rods produced by direct percussion splitting. If the technique used is the same as the one used for retoucher blanks, the impact points are less marked and the notches are less invasive (fig. 7). The microcracks under the impacts and the traces of tearing at the level of the fracture edges (fig. 7, A) are much more frequent. The methods of debitage would therefore be significantly different (variation in the applied strength, in the gesture, in the nature of the hammer, of the anvil...). Even if they are made on taxonomically and anatomically identical blocks, pressure flakers and retouchers are not necessarily resulting from the same manufacturing chain. In the case of pressure flakers, the giving of a greater number of blows but of less intensity (a phenomenon responsible for the development of microcracks) could be explained by the need to better control the propagation of the fracture line, in order to obtain, notably, longer blanks. A necessity that can in turn be explained by the functioning modes and therefore by a different grasping of both tools. The shaping stages of the blanks are limited to rare cases of straightening out of the fracture edge by adzing (Baumann and Maury 2013; Baumann 2014; fig. 7, B). 


\subsection{4 - Use}

The active part of a pressure flaker is formed by a point with a tip, that it to say a contact surface perpendicular to the axis of the shaft. Apart from the raw material, the capacity of a point to absorb the mechanical stress is related to its dimensions and especially to the thickness of the tip that will guarantee the resistance at the time of the tearing gesture (Texier 1984). The tips of the pressure flakers of the corpus have thicknesses between $0.3 \mathrm{~cm}$ and $0.6 \mathrm{~cm}$ and widths ranging from $0.6 \mathrm{~cm}$ to $1.5 \mathrm{~cm}$. These thicknesses are relatively small (on average $0.48 \mathrm{~cm}$ ) compared with pressure flakers in southwestern sites (on average $0.75 \mathrm{~cm}$; Baumann 2014). Thus, if the pressure force is limited by the raw material (see paragraph 3.2.1.), the tearing force (Texier, 1984) is limited by the thickness of the tips. The operations that can be carried out with the Rochefort pressure flakers are thus limited to small-scale retouching.

Figure 7 - Manufacturing traces on pressure flakers.
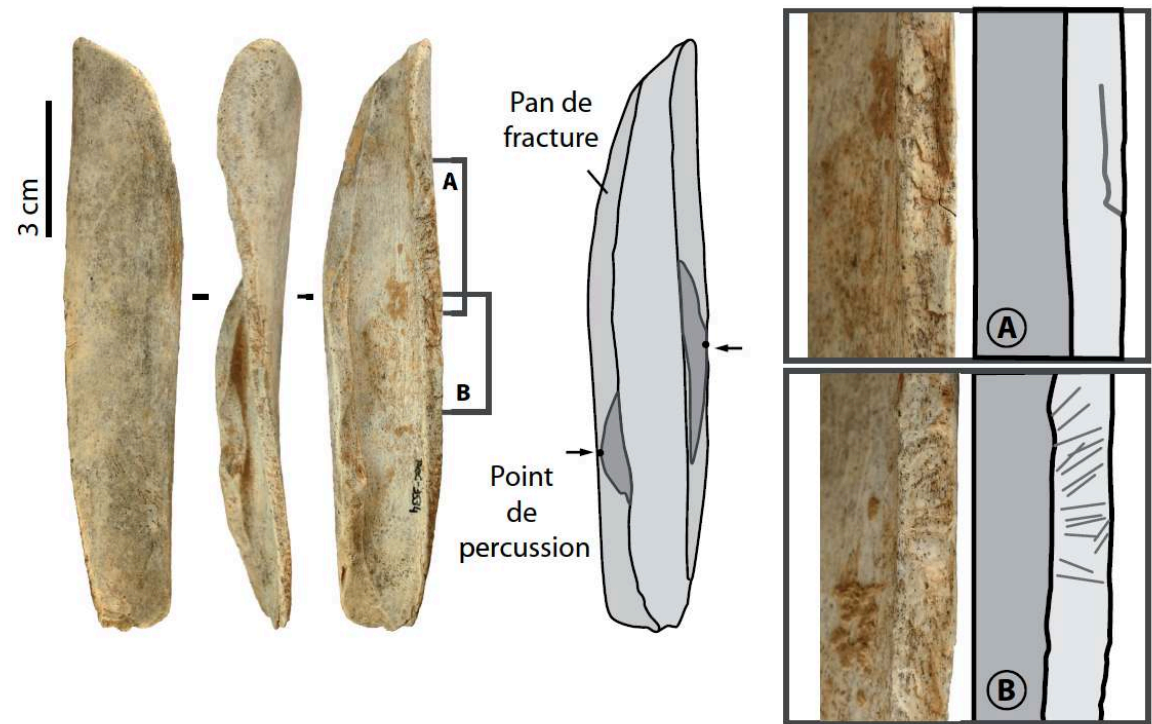

A - cracks ; B - cuts.

(Photos and CAD by M. Baumann)

The traces of use are: (1) impressions resulting from the driving in of the pressure point in the tip of the pressure flaker (fig. 8, No. 1), (2) striations resulting from the moving of the pressure point on the pressure flaker tip, (3) splintering or material removals that show an accidental damage of the tip (fig. 8, No. 5) and (4) compaction resulting from repeated crushing of the tip against the lithic edge (Baumann 2014). We can also add (5) the hollows caused by a loss of material, due to an accumulation of impressions in the same zone of the tip (fig. 8, No. 2). Finally, the pressure flakers tips are (6) generally faceted. We believe that this faceting, although accentuated by use, is part of the initial volumetric configuration of the active part (fig. 8, A, B and C; ibid).

On the pressure flakers of Rochefort, the impressions, common to all the objects, are few in number, except on rare pieces where hollows have formed. In the latter cases, the traces remain confined to the same zone of the tip, showing the repetition of the same gesture of retouching, that is to say carrying out the same type of operation. 
Striations and compaction are not systematic. More superficial than the impressions, their disappearance can be partly attributed to taphonomic alterations particularly marked on the active parts. The splintering are rather frequent and of variable dimensions. They form after a certain period of use. As the retouching progresses, the tip loses material, either homogeneously (it tends to tilt) or heterogeneously (forming zones of depressions). In both cases, the gripping point between the pressure flaker and the lithic edge shifts, reducing the thickness of the material supposed to withstand the pressure. The tip is no longer able to take the applied force and the splinters detach in the axis of the retouching gesture. In the corpus, the frequency of the splintering can be explained by the low thickness of the tips and shows that the pressure flakers were used to the limit of their capacities.

The choice of bone as a raw material (limiting the applicable force), the low investment in the manufacturing steps (absence of shaping), the volumetric configuration of the active parts (reduced thickness of the tip) and the nature of the traces (low intensity, splintering), suggest that the pressure flakers of the corpus are expedient tools, used occasionally and not always in a suitable way.

\section{3 - Awls (5 pieces)}

Awls are common to almost all prehistoric societies. This is due not to the actual permanency of a particular type of tool, but to the grouping together in the same category of objects responding to the very general feature of having a pointed active part; the choice of denomination (point, awl, pin, needle, etc.) generally refers to an appreciation of their degree of shaping rather than to a functional identification. Often associated with the working of hides, H. Camps-Fabrer reminds us that "other activities, some of which we have missed, may have created use of it" (Camps-Fabrer 1990 - p.1). These pointed objects, which we will call awls for convenience, are probably, for this reason, the best represented category in the Solutrean bone industries (Baumann 2014).

The corpus consists of 5 specimens: two on medium mammalian ulna (fig. 9, No. 1), a frequent blank for Solutrean awls, two on an undetermined diaphysis fragment and one on a vestigial horse metapodial (fig. 9, No. 3). Note that the old collections from Rochefort constituted by R. Daniel, also yielded two awls made on this same type of blank (fig. 9, No. 4). The a priori whole specimens have relatively comparable lengths, around $8.8 \mathrm{~cm}$. The widths, from $0.4 \mathrm{~cm}$ to $1.6 \mathrm{~cm}$, are more varied and refer to the widths of the chosen anatomical supports. The pieces on ulna are not much shaped. We have included them in the awl category because of the blank, the lack of the articular head and the presence of a bending fracture on fresh materials at the opposite end (fig. 9 , A). The object made on vestigial metapodial is entirely worked, but the investment in the manufacturing phase remains limited insofar as the object follows the general shape of the bone, naturally pointed and tapered. Apart from small bending fractures at the distal end, no trace related to the use could be detected.

\section{4 - Retouched flakes (2 pieces)}

Two pieces have been singled out because they have on one of their edges a series of retouching that can be likened to a preparation and/or a use of this edge as an active 
tool part (fig. 9, 2, B). In both cases, they are diaphysis flakes, one being from the femur of an equid. We do not know if these pieces are whole and which activity(ies) they may have participated in.

\section{4 - Reindeer antler}

The antlers of the corpus are exclusively reindeer antlers. The variability of sizes and that of the thickness of compact tissue show that they come from juveniles and adult individuals, male or female. When they can be identified, these antler are always shed antler. The anatomical elements used are located in the lower part of the antler (base, beam and tines). Even if a piece probably relates to the palm, the recovered antlers may have been cleared of their upper part before being brought back to the site or at least in this area of the cave. There does not appear to be any privileged exploitation of a particular type of antler or anatomical part. Nevertheless, we must emphasize the presence of a relatively large amount of juvenile antler (fig. 10 and 11, No. 1), in proportions that we have never observed in other Solutrean sites. As they are shed antlers, we know that they were intentionally collected.

Figure 8 - Use-wear traces on pressure flakers.
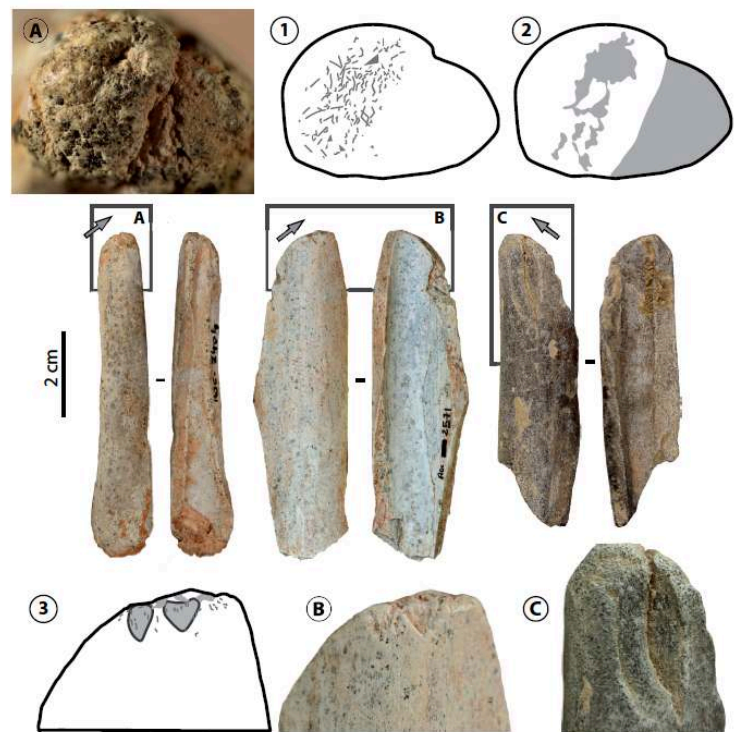

(c)
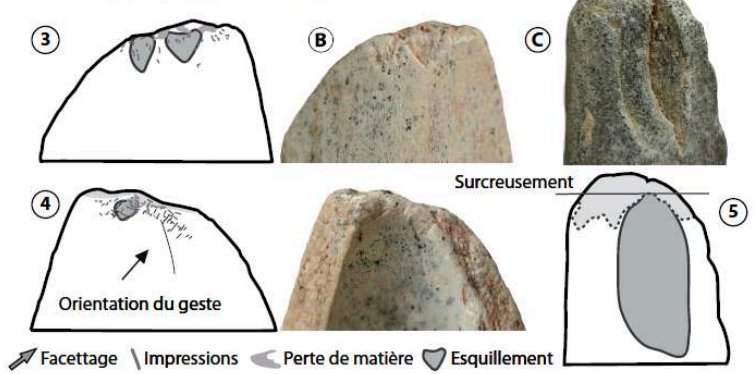

A - Tip of the pressure flaker $n^{\circ} 2404$ (layer 4.3) ; B - Upper and lower edge of the tip of the pressure flaker $n^{\circ} 2571$ (c. 4.3); $C$ - Upper edge of the tip of the pressure flaker $n^{\circ} 556$ (c. 4.1$) ; 1$ - impressions ; 2 - loss of material ; 3 -impressions + loss of material on upper edge ; 4 -impressions + loss of material + splintering on lower edge; 5 - splintering.

(Photos and CAD by M. Baumann) 


\section{1 - Manufacturing remains (42 pieces)}

The assemblage of industry on antler from Rochefort consists of manufacturing remains, 9 of which were on juvenile antler and 29 on antler from adult individuals. Nine pieces, the great majority of them crown tines, cannot be attributed to any category of individuals (see fig. 10).

The small size antler (juvenile): the corpus consists of a half-section on a second tine and 8 full sections, 6 of which comprise the base part, the inter-tine space and part of the beam A (fig. 11, No. 1). These pieces represent two different levels of processing. The sections have undergone only one reduction phase ("reduction sequence", Pétillon and Ducasse 2012): a transverse cutting (to the direction of the fibers) of the initial block. The hemi-section is the result of two successive reduction phases: a transverse division of the block followed by a longitudinal cutting of the section thus obtained.

In the first phase of reduction, second tines are systematically severed at their base by a bifacial adzing that hardly penetrates the thickness of the compact tissue. They are then detached by bending. In two cases, the cutting is carried out only by bending. The beams $\mathrm{A}$ are also cut by adzing, which this time can also penetrate the compact tissue in depth. The sectioning is located high enough on the beam (see fig. 11, No. 1), except in one case where it is carried out at the inter-tine space. The operations carried out produce: (1) beam sections, the length of which does not appear to be decisive (see sectioning zones) but which, on juvenile antler, form relatively straight and regular elements; (2) sections of second tines, this time of flattened section, probably taken up to the maximum of their length (see sectioning zones); (3) sections of basal parts with part of the beam A. In the latter case, the pieces taken into account would no longer be wastes but products of the processing chain. A second reduction phase is visible on the hemi-section. After transversal division at both ends, the object is separated longitudinally by splitting.

The medium / large size antlers (compact thickness equal to or greater than $0.6 \mathrm{~cm}$ ): the corpus comprises 2 basal parts (fig. 11, No. 3), 1 section of beam (fig. 11, No. 2), crown tines, elongated fragments of the rod type (fig. 12, No. 1, No. 3) and small flakes (fig. 12, No. 4). These objects have undergone at least one to two reduction phases.

The beams, first and second tines were cut by adzing and then bending and in one case by simple bending (first tine). The adzing is much deeper than on the antler of small size, but as on the latter, the beam A is cut at half height (fig. 11, A), while the tines are sectioned at their base (fig. 11, B). The crown tines are eliminated by simple bending. The group of elongated fragments comprises rods of variable dimensions obtained by longitudinal splitting (in the direction of the fibers) in direct percussion (fig. 12, A and B). The shortest objects show sectioning by bending, after longitudinal splitting, at one of their ends. In one case, bending is prepared by adzing. The last two pieces are small flakes detached as a result of direct percussion (see fig. 12, No. 4). 
Figure 10 - Anatomical location of antler artefacts from Rochefort cave.

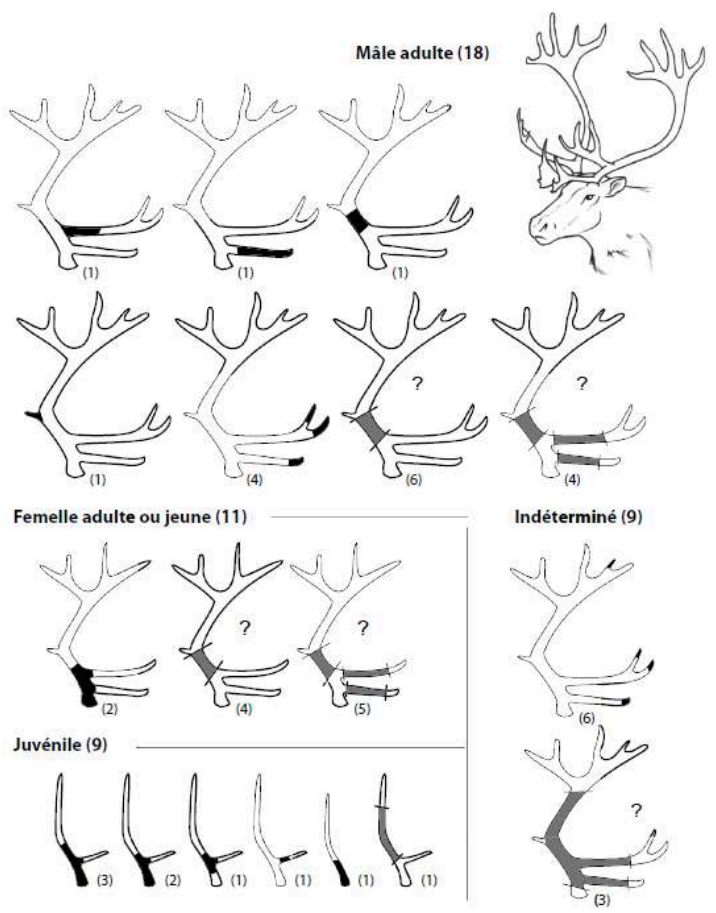

(Drawing and CAD by M. Baumann) 
Figure 11 - Remains from antler working.

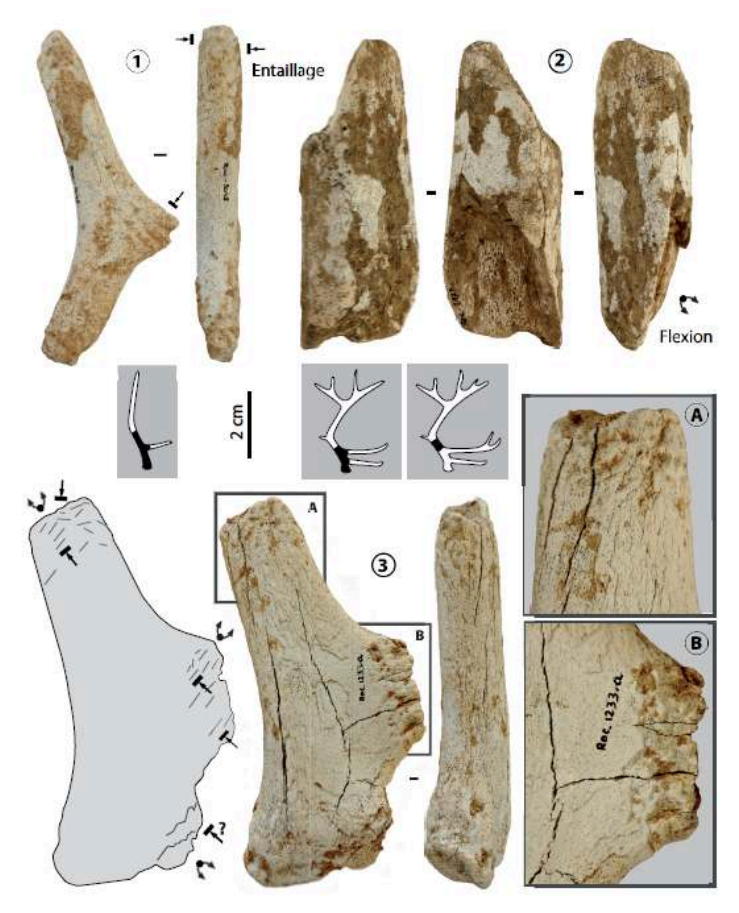

$1-n^{\circ} 3042$ (layer 4.3); 2 - n 4238 (I. 4.4); 3 - n 1233a (c. 4.2); A - cutting of beam A by adzing; B cutting of the second tine by adzing.

(Photos and CAD by M. Baumann)

The basal parts sections and the beam section can belong to the same type of processing chain: that of the intermediary tools made on first and second tines. On the other hand, the fractured fragments do not find any match among the finished objects.

In the Solutrean osseous industries, a production on reindeer antler using direct percussion splitting is evidenced by the presence of numerous tools on fractured supports: mainly pressure flakers, but also intermediary tools and projectile points. On the other hand, waste belonging to this type of chain is rare in the archaeological collections. A series of experiments on the fracturing of reindeer antler has nevertheless allowed us to propose a chaîne opératoire whose wastes and products are morphologically and technologically comparable to the archaeological specimens (Baumann and Maury 2013; Baumann 2014). From this model, the crown tines and the sections of basal parts in the corpus can be interpreted as waste, the sections of beam and tines as prepared blocks intended to be divided into blanks and the elongated fragments as blanks. Fragments divided transversely after longitudinal splitting could be trimming waste whereas small fragments would be accidentally generated at the time of debitage of the blanks.

On the site there is therefore a possible production of tool blanks on reindeer rods. The absence of this tool in the studied corpus can be explained by: (1) the export of the products off site or (2) the use on site outside the excavated area. In the old collections, some antler tools of medium and large sizes could validate this last hypothesis. 


\section{2 - Tools (4 pieces)}

The tools on reindeer antler are represented by a point fragment on an indeterminate blank and three intermediary tools

The intermediary tools belong to the large category of beveled tools, but we prefer to dissociate them because their end is not systematically beveled. We identify them from the most characteristic traces of use: damage caused by repeated percussion. These pieces appear as early as the early Aurignacian and are made out of deer antler or bone, the latter category often being underestimated on the sites (Tartar 2009, 2012b). In the Solutrean, the percussed tools are mostly on cervid antler tine (Agoudjil 2004 and 2005; Baumann 2014).

40 The three pieces of the corpus are made of reindeer antler of large size, although we have hesitated on the attribution of the third specimen whose spongy tissue is particularly loose. The first two pieces are respectively on second tine base and first tine distal end (fig. 13, Nos. 1 and 2). If the third piece is indeed made of cervid antler, it could be located at the level of the lower part of the antler (base and / or start of beam A). These tools have in common a significant thickness i.e. respectively $2.7 \mathrm{~cm}, 1.7 \mathrm{~cm}$ and $1.2 \mathrm{~cm}$. The morphologies of the distal active parts differ considerably. The one of the specimen on second tine is beveled, while the one the first tine is pointed and the third has a thick slightly convex front, as wide as the proximal part.

The cutting of the tines was prepared by adzing at least on one face and completed by bending. The first tine is not shaped. On the second tine, the shaping is limited to fracturing by direct percussion on anvil (diametrically opposite percussion notches) to create the bevel. The blank of the third object is of the rod type. The preserved traces do not allow to determine the techniques of the first phases of the processing, but the morphology of the edge and the width of the blank are close to those observed on the products resulting from blank production by splitting. The piece was then scraped. On the three objects, the poor state of surface preservation does not allow a complete analysis of the traces of use. The percussion of the proximal ends is revealed by a compacted surface, and also on the first tine by removing material on one of the lateral edges and on the external edge. The tool on the rod shows a fracture in flexion beneath the percussed zone, which can be caused by a manufacturing operation as well as by use. The variations in the configuration of the active parts are probably due to functional differences. 
Figure 12 - Remains from antler working of middle and large size, fragments.

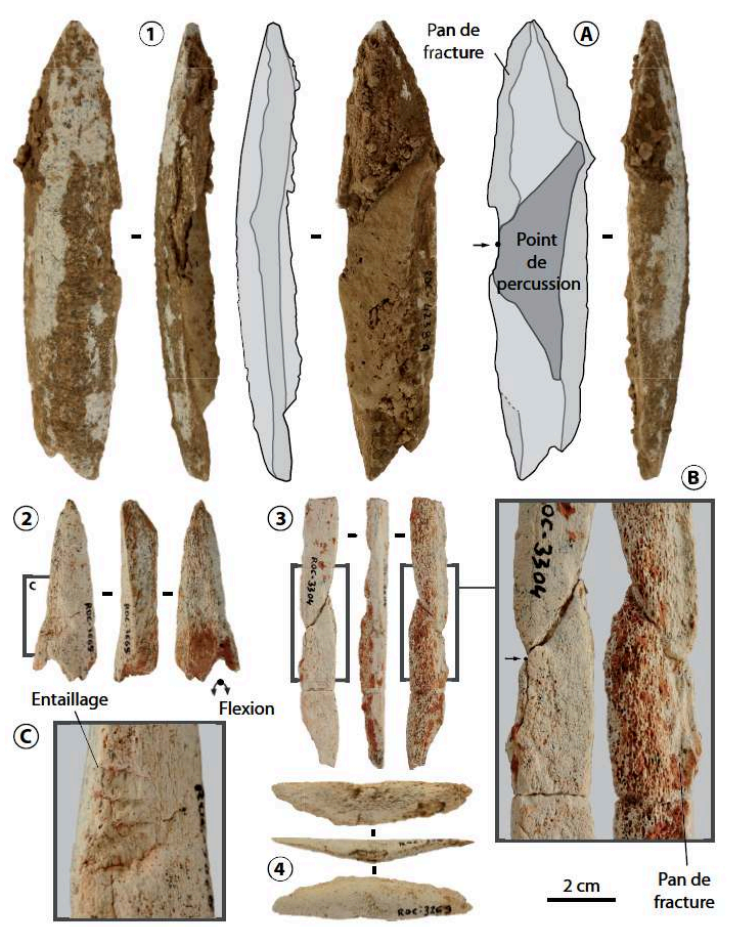

$1-n^{\circ} 4238$ (layer 4.4); 2 - n 3665 (I. 4.3); 3 - n 3304 (I. 4.3); 4 - n 3269 (I. 4.4); A et B - longitudinal splitting by direct percussion; $\mathrm{C}$ - transversal division by adzing and bending. (Photos and CAD by M. Baumann) 
Figure 13 - Intermediate tools from Rochefort cave.

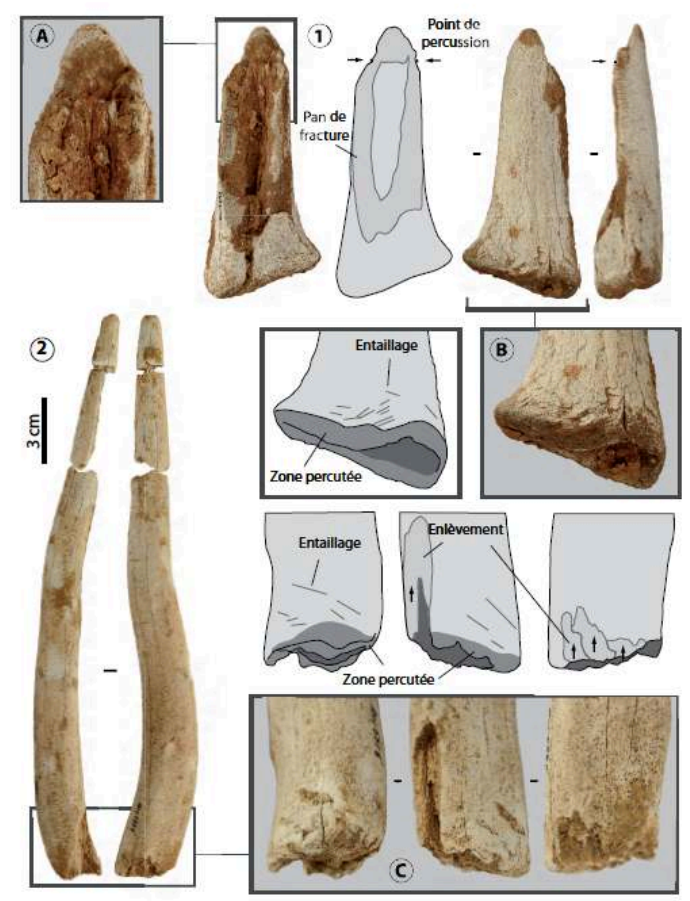

1 - on second tine, $n^{\circ} 2713$ (layer 4.3); 2 - on first tine, $n^{\circ} 5578$ (c. 4.5); A - beveled end made by direct percussion; $\mathrm{B}$ et $\mathrm{C}$ - percussed end cut by adzing.

(Photos and CAD by M. Baumann)

\section{Conclusion}

The osseous industry from the recent excavations of the Rochefort cave constitutes a homogeneous corpus that fits well into a Solutrean technical environment. Reindeer antler is divided transversely by adzing and/or longitudinally by direct percussion. The waste collected do not allow to reconstruct the complete processing chains but are compatible with the proposed debitage methods for the sites of the late Solutrean of southwestern France (Baumann and Maury 2013; Baumann 2014). The reconstruction of the processing chains for the osseous objects must go through a systematic refitting of all fractured faunal remains. For both bone and reindeer antler, economic issues (i.e. system-wide) cannot be addressed because it is not possible in the present state of the excavations, to evaluate the representativeness of the surveyed sector in relation to the totality of the Solutrean settlement of the cave.

Among the finished objects, the pressure flakers, tools of the lithic retouching by pressure, validate the attribution of the levels to a late Solutrean. However, they have the peculiarity of being on bone, a feature that could directly derive from the environmental context, the difficulty in supplying antler from male adult animals, and the choice of lithic materials exploited. The degree of shaping and use of the tools shows that they are of the expedient type whereas the low morphometric variability and the configuration of the traces attest to a relative standardization of the operations carried out. These features are in contrast to those of the Daniel collection, which was 
built in the 1930s and is kept in the National Archeology Museum in Saint-Germain-enLaye. More widely made of cervid antler, the shaping and use of these latter pieces among which a sub-triangular projectile point, a pressure flaker on large size reindeer antler, fragments of ivory and intermediary tools on rods - are more advanced. Thus the corpus from the recent excavations complements the one of the old excavations, but not only.

In the new assemblage of industry, the absence of typologically remarkable pieces could also give information on the nature of the area surveyed, for "a clear gradient is evident [in the density of the remains] from the back of the cave toward its center, up to the excavation limit, suggesting that the heart of the Solutrean dwelling is situated in the larger part of the hall" (Hinguant and Colleter 2010, p.39). Thus, the nature of the osseous industry coupled with the spatial distribution of all the material would suggest that the sector in question is a zone of rejection or secondary activity. Excavations must therefore be continued in order to be able to answer some questions such as the purpose of the productions on juvenile reindeer antler (of which some scraped ones are also known in the Peyrony collections of the site of Fourneau du Diable), of the fractioning of the production chains of the larger size antler tools in time and in space, or that of the variability of the exploitation strategies of lithic materials and their implications for the osseous toolkit.

\section{BIBLIOGRAPHY}

\section{References}

ABRAMS G., BELLO S.M., DI MODICA K., PIRSON S., BONJEAN D. 2014 - When Neanderthals used cave Bear (Ursus spelaeus) Remains : Bone Retouchers from Units of Scladina Cave (Belgium). Quaternary International, 326-327, p. 274-287.

AGOUDJIL A. 2004 - L'industrie en matières dures animales du site solutréen du Roc-de-Sers (Sers, Charente), Exploitation du bois de renne : contribution d'une approche technologique et typologique à la reconnaissance d'une période chrono-culturelle. Mémoire de Maîtrise, Université de Paris I, Panthéon-Sorbonne, 111 p.

AGOUDJIL A. 2005 - Essai de caractérisation des industries en matières dures animales solutréennes, Apport de l'étude du niveau solutréen moyen (couche $\mathrm{H}$ » à feuilles de laurier) de Laugerie-Haute Ouest à la connaissance des modalités de débitage du bois de cervidé. Mémoire de D.E.A., Université de Paris I, Panthéon-Sorbonne, 62 p.

ARMAND D., DELAGNES A. 1998 - Les retouchoirs en os d'Artenac (couche 6c) : perspectives archéozoologiques, taphonomiques et expérimentales. In : J.-P. Brugal, L. Meignen et M. PatouMathis (dir.), Économie préhistorique : les comportements de subsistance au Paléolithique. XVIII ${ }^{\mathrm{e}}$ Rencontres internationales d'archéologie et d'histoire d'Antibes. Antibes, APDCA, p. 205-214. 
AUBRY T., WALTER B., ALMEIDA M., LIARD M., NEVES M.-J. 2004 - Approche fonctionnelle des sites dits d'atelier : l'exemple des occupations solutréennes et badegouliennes du site des Maîtreaux (Indre-et-Loire, France). In : P. Bodu et C. Constantin (dir.), Approches fonctionnelles en Préhistoire. Actes du XXV e Congrès préhistorique de France, Nanterre (24-26 novembre 2000). Paris, Société préhistorique française, p. 249-263.

BAUMANN M. 2014 - À l'ombre des feuilles de laurier, les équipements osseux solutréens du Sud-Ouest de la France : apports et limites des collections anciennes. Paris, Université Paris 1, Thèse de doctorat, 593 p.

BAUMANN M., MAURY S. 2013 - Ideas no longer written in antler. Journal of Archaeological Science, 40 (1), p. 601-614.

BAUMANN M., PESCHAUX C. 2014 - De l'équipement à la parure, quelques éléments de distinction des industries osseuses solutréennes. In : J. Jaubert, N. Fourment et P. Depaepe (dir.), Transitions, ruptures et continuité durant la Préhistoire. Actes du XXVII ${ }^{\mathrm{e}}$ Congrès Préhistorique de France, Bordeaux-Les Eyzies-de-Tayac, 31 mai-5 juin 2010, vol. 2, p. 355-370.

BEMILLI C., HINGUANT S. 2014 - Premiers résultats sur les comportements de subsistance solutréens à la grotte Rochefort (Mayenne, France). In : S. Ripoll López (coord.), De punta a punta. El Solutrense en los albores del siglo XXI. Actas del Congreso Internacional "El Solutrense. Centenario de las excavaciones en La Cueva de Ambrosio", Vélez-Blanco, Almería (España), 25-29 juin 2012. UNED, Espacio, Tiempo y Forma, Serie I, Prehistoria y Arqueología (5), p. 309-321.

BIARD M., HINGUANT S., 2015 - Regard typo-technologique sur les productions lithiques foliacées du Solutréen de la vallée de l'Erve (Mayenne, France). Bulletin de la Société préhistorique française, 112 (2), p. 213-234.

BLUMENSHINE R. J. 1996 - Blind Tests of Inter-analyst Correspondence and Accuracy in the Identification of Cut Marks, Percussion Marks, and Carnivore Tooth Marks on Bone Surfaces. Journal of Archaeological Science, 23, p. 493-507.

BODU P., DUMARCAY G., NATON H.-G., avec la coll. de BALLINGER M., THÉRY-PARISOT I. 2014 Un nouveau gisement solutréen en Île-de-France, le site des Bossats à Ormesson (Seine-etMarne). Bulletin de la Société préhistorique française, 111 (2), p. 225-254.

BORAO ÁLVAREZ M., VILLAVERDE BONILLA V., AURA TORTOSA J.E. 2016 - Debitage by fracturing in the osseous industry of Cova del Parpalló (Gandia-Valencia, Spain), a preliminary study. Quaternary International, http://dx.doi.org/10.1016/j.quaint.2015.12.020.

CAMPS-FABRER H. 1990 - Fiche générale. In : H. Camps-Fabrer, D. Ramseyer, D. Stordeur (dir.), Fiches typologiques de l'industrie de l'os préhistorique, Cahier III : poinçons, pointes, poignards, aiguilles. Commission de nomenclature sur l'industrie osseuse préhistorique. Aix-en-Provence, éditions de l'Université de Provence, p.1.

CAMPS-FABRER H., RAMSEYER D. 1992 - Fiche baguette simple en bois de cerf. In : H. BargeMahieu, H. Camps-Fabrer, V. Feruglio, A. Peltier et D. Ramseyer (dir.), Fiches typologiques de l'industrie osseuse préhistorique, Cahier V: Bâtons percés, baguettes. Commission de nomenclature sur l'industrie de l'os préhistorique. Treignes, éditions du CEDARC, p. 85-93.

CASTEL J.-C. 2003 - Économie de chasse et d'exploitation de l'animal au Cuzoul de Vers (Lot) au Solutréen et au Badegoulien. Bulletin de la Société préhistorique française, 100 (1), p. 41-65.

CASTEL J.-C., CHAUVIÈRE F.-X., MADELAINE S. 2003 - Sur os et sur dents : les « retouchoirs » aurignaciens de la Ferrassie (Savignac-de-Miremont, Dordogne). Paleo, 15, p. 29-50. 
CHASE P. G. (1990) - Tool-making Tools and Middle Paleolithic Behavior. Current Anthropology, 31, p. 443-447.

CHEYNIER A. 1949 - Badegoule, station solutréenne et proto-magdalénienne. Paris, archives de l'Institut de Paléontologie Humaine, mémoire 23, Masson, 230 p., 114 fig.

DALEAU F. 1883 - Sur des lésions que présentent certains os de la période paléolithique. Congrès de l'Association Française pour l'Avancement des Sciences, $12^{\mathrm{e}}$ session, Rouen, p. 600-602.

D'ERRICO F., BACKWELL L.R., WADLEY L. 2012 - Identifying regional variability in Middle Stone Age bone technology: The case of Sibidu Cave. Journal of Archaeological Science, 39 (7), p. 2479-2495.

GALÁN A. B., RODRÍGUEZ M., JUANA S.D., DOMIGUEZ-RODRÍGO M. 2009 - A new experimental study on percussion marks and notches and their bearing on the interpretation of hammerstonebroken faunal assemblages. Journal of Archaeological Science, 36, p. 776-784.

HANQUET C., DESCLAUX E., HINGUANT S. 2016 - Les rongeurs des niveaux solutréens de la grotte Rochefort (Saint-Pierre-sur-Erve, Mayenne) : un référentiel inédit pour le Dernier Maximum Glaciaire du nord-ouest de la France. Quaternaire, 27 (4), p. 341-352.

HENRI-MARTIN L. 1906 - Maillets ou enclumes en os provenant de la couche moustérienne de la Quina (Charente). Bulletin de la Société préhistorique française, 3, p. 155-162.

HINGUANT S., COLLETER R. (dir.), avec les contributions de ARELLANO A., BEAREZ P., BEMILLI C., BIARD M., BODINIER B., CHAUT J.-J., DEBRET M., DESCLAUX E., EL GUENNOUNI K., HANQUET C., LAIGNEL B., LENORMAND A., MARCOUX N., MOULLÉ P.-É., NOËL F., PESCHAUX C., PIGEAUD R., POMMIER V., RODET J., ROGER T., TSOBGOU AHOUPE R. et VISSAC C., 2010 - Le Solutréen de la grotte Rochefort (Saint-Pierre-sur-Erve, Mayenne). Rapport de fin d'opération triennale 2008-2010, campagne 2010 (3/3). UMR 6566 du CNRS, Rennes, 210 p., 129 fig., 29 tabl., annexe 115 p., inédit.

HINGUANT S., BIARD M. 2013 - Le Paléolithique supérieur ancien de la vallée de l'Erve (Mayenne) : un état des connaissances. In : P. Bodu, L. Chehmana, L. Klaric, L. Mevel, S. Soriano et N. Teyssandier (dir.) "Le Paléolithique supérieur ancien de l'Europe du Nord-Ouest : réflexions et synthèses à partir d'un projet collectif de recherche sur le centre et le sud du Bassin parisien". Actes du colloque européen « Le Paléolithique supérieur ancien de l'Europe du Nord-Ouest (35000-15000 BP) », séance de la Société préhistorique française, Sens (15-18 avril 2009), Paris, éd. Société préhistorique française, Mémoire LVI, p. 239-250.

HINGUANT S., BIARD M., MOULLÉ P.-É., PIGEAUD R. 2013 - La vallée de l'Erve (Mayenne) : présence solutréenne au nord de la Loire. In : Société d'études et de recherches archéologiques sur le Paléolithique de la vallée de la Claise (dir.), "Le Solutréen... 40 ans après Smith'66 ". Actes du colloque international de Preuilly-sur-Claise (28 oct.-01 nov. 2007). Tours, éd. Archéa-Feracf, revue archéologique du Centre de la France, suppl. 47, p. 247-260.

HINGUANT S., MOULLÉ P.-É., ARELLANO A., PIGEAUD R. 2012 - Pièces osseuses gravées du Solutréen moyen de la Grotte Rochefort (Saint-Pierre-sur-Erve, Mayenne, France). Paleo, 23, p. 337-356.

JÉQUIER C. A., ROMANDINI M., PERESANI M. 2012 - Les retouchoirs en matières dures animales : une comparaison entre Moustérien final et Uluzzien. Comptes rendus Palevol, 11, p. 283-292.

LEROY-PROST C. 2002 - Fiche canines de carnivores. In : M. Patou-Mathis (dir.), Fiches typologiques de l'industrie osseuse préhistorique, Cahier X : retouchoirs, compresseurs, percuteurs os à impressions et éraillures. Commission de nomenclature sur l'industrie de l'os préhistorique. Aix-en-Provence, Publications de l'Université de Provence, p. 99-104. 
MAIGROT Y. 2003 - Étude technologique et fonctionnelle de l'outillage en matières dures animales, La station 4 de Chalain (Néolithique final, Jura, France). Paris, Université de Paris I, Thèse de doctorat, $284 \mathrm{p}$.

MALLYE J.-B., THIÉBAUT C., MOURRE V., COSTAMAGNO S., CLAUD É., WEISBECKER P. 2012 - The Mousterian Bone Retouchers of Noisetier Cave : Experimentation and identification of marks. Journal of Archaeological Science, 39, p. 1131-1142.

PATOU-MATHIS M. (dir.) 2002 - Fiches typologiques de l'industrie osseuse préhistorique, Cahier X: retouchoirs, compresseurs, percuteurs os à impressions et éraillures. Commission de nomenclature sur l'industrie de l'os préhistorique. Aix-en-Provence, Publications de l'Université de Provence.

PÉTILLON J.-M., AVERBOUH A. 2012 - Le travail du bois de renne dans les couches badegouliennes. In : J. Clottes, J.-P. Giraud, P. Chalard (dir.), Solutréen et Badegoulien au Cuzoul de Vers, Des chasseurs de Renne en Quercy. Presses de l'Université de Liège (ERAUL 131), p. 359-386.

PÉTILLON J.-M., DUCASSE S. 2012 - From flakes to grooves: a technical shift in antlerworking during the Last Glacial Maximum in southwest France. Journal of Human Evolution, 62, p. 435-465.

PICKERING T. R., EGELAND C. P. 2006 - Experimental patterns of hammerstone percussion damage on bone: implications of inferences of carcass processing by human. Journal of Archaeological Science, 33, p. 459-469.

RÉMY D. 2013 - Caractérisation techno-économique d'industries en bois de cervidés du Badegoulien et du Magdalénien, le cas du Rond-du-Barry (Haute-Loire) et de Rochereil (Dordogne). Montpellier, Université de Montpellier III, Thèse de doctorat, 358 p.

RENARD C. 2008 - Les premières expressions du Solutréen dans le Sud-Ouest français, évolution technoéconomique des équipements lithiques au cours du dernier maximum glaciaire. Paris, Université Paris X - Nanterre, Thèse de doctorat, $448 \mathrm{p}$.

RIGAUD A. 2004 - Débitage du bois de renne dans les couches badegouliennes de l'Abri Fritsch (Indre, France). In : Ramseyer D. (dir.), Fiches de la commission de nomenclature sur l'industrie de l'os préhistorique, Cahier XI : Matière et technique. Paris, édition de la Société préhistorique française, $\mathrm{p}$. 75-78.

ROMANDINI M., CRISTIANI E., PERESANI M. 2014 - A retouched Bone Shaft from the Late Mousterian at Fumane Cave (Italy). Technological, Experimental and Micro-wear Analysys. Comptes rendus Palevol, 11(4), p. 283-292.

SCHWAB C. 2002 - Fiche éclats diaphysaires du Paléolithique supérieur : La grotte d'Isturitz (Pyrénées-Atlantiques). In : M. Patou-Mathis (dir.), Fiches typologiques de l'industrie osseuse préhistorique, Cahier $\mathrm{X}$ : retouchoirs, compresseurs, percuteurs os à impressions et éraillures. Commission de nomenclature sur l'industrie de l'os préhistorique. Aix-en-Provence, Publications de l'Université de Provence, p. 59-69.

SCHWAB C. 2014 - Les « os à impression » de la grotte d'Isturitz (Pyrénées-Atlantiques). Paris, Thèse de l'Ecole du Louvre.

TARTAR É. 2009 - De l'os à l'outil, caractérisation technique, économique et sociale de l'utilisation de l'os à l'Aurignacien ancien, étude de trois sites : l'Abri Castanet (secteur nord et sud), Brassempouy (Grotte des Hyènes et Abri Dubalen) et Gatzarria. Paris, Université Paris I, Panthéon-Sorbonne, Thèse de doctorat, 2 vol., 310 p. et 63 p.

TARTAR É. 2012a - Réflexion autour de la fonction des retouchoirs en os de l'Aurignacien ancien. Bulletin de la Société préhistorique française, 109 (1), p. 69-83. 
TARTAR É. 2012b - The recognition of a new type of bone tools in Early Aurignacian assemblages: implications for understanding the appearance of osseous technology in Europe. Journal of Archaeological Science, 39, p. 2348-2360.

TEXIER P.-J. 1984 - Le débitage par pression et la mécanique de la rupture fragile, initiation et propagation des fractures. In : J. Tixier, M.-L. Inizan et H. Roche (dir.), Préhistoire de la pierre taillée, II - Economie du débitage laminaire : technologie et expérimentation. III $^{\mathrm{e}}$ table ronde de technologie lithique de Meudon-Bellevue (octobre 1982). Meudon, Cercle de recherches et d'études préhistoriques, p. 139-147.

TEYSSANDIER N., RENARD C., BON F., DESCHAMPS M., GARDÈRE P., LAFITTE P., NORMAND C., TARRIŇO A. 2006 - Premières données sur le site de Marseillon (Banos, Landes) : un nouveau gisement solutréen de plein air en Chalosse? Archéologie des Pyrénées Occidentales et des landes, 25, p. $105-120$.

TIFFAGOM M., AURA TORTOSA J.E., VILLAVERDE BONILLA V., FULLOLA PERICOT J.M. 2007 - Entre Gravettien et Solutréen en Espagne méditerranéenne : mise en évidence d'une phase intermédiaire à composante mixte ? In : M. Almeida, B. Walter et M.J. Neves, Le Solutréen... 40 ans après Smith'66. Pré-actes du colloque international de Preuilly-sur-Claise (28 octobre -1er novembre 2007), p. 18-19.

TURNER C. G. 1983 - Taphonomic Reconstitution of Human Violence and Canibalism Based on Mass Burials in the American Southwest. In, G. M. Lemoine, A. S. MacEachern (Eds.), Carnivores, Human Scavengers and Predators: A Question of Bone Technology, University of Caigary Archaeological Association, Calgary, p. 219-240.

ZILHÃO J., AUBRY T. 1995 - La pointe de Vale Comprido et les origines du Solutréen.

L'Anthropologie, 99 (1), p. 125-142.

\section{ABSTRACTS}

Recently discovered Solutrean sites have provided little data about bone working. Solutrean bone industry is mainly known through old archaeological collections from the first half of the $20^{\text {th }}$ century or out of context and very incomplete. The resumption of old excavations, such as in Rochefort cave, far from bringing redundant information, opens up new research perspectives. Beside projectile points, awls, "bâtons percés" and other long-known typological objects, artefacts identified by discreet features resulting from their manufacture and use can be added. The identification of these "unshaped tools" is the consequence of methodological changes and first of all of the increase of use-wear studies and of a more systematic use of the experimental approach. Thus, in Rochefort cave, implements devoted to lithic knapping are completing the Solutrean toolkit while about fifty waste from reindeer antler working confirm blank production by splitting. These artefacts help to understand the specificity of Solutrean bone technology. They enlighten the activities carried out on the site and the peculiarities of a northern Solutrean still insufficiently documented. In the present state of research, they also illustrate the interest to excavate again old sites that may still have a strong informative potential.

\section{INDEX}

Keywords: Solutrean, technology, bone industry, toolkit, bone retouchers, pressure flakers, antler knapping, Rochefort Cave, Mayenne, France 


\section{AUTHORS}

\section{MALVINA BAUMANN}

UMR 5199, Laboratoire PACEA « De la Préhistoire à l'Actuel, Culture, Environnement, Anthropologie », Université de Bordeaux, Bâtiment B18, Allée Geoffroy St-Hilaire CS 50023, FR-33615 Pessac cedex - malvina.baumann@gmail.com

\section{STÉPHAN HINGUANT}

INRAP-Bretagne, 37 rue du Bignon, 35577 Cesson-Sévigné, France et UMR 6566 CNRS CReAAH «Centre de Recherche en Archéologie Archéosciences Histoire », CNRS, Université de Rennes 1, Rennes 2, Nantes et Ministère de la Culture ; Bâtiment 24-25, Université de Rennes 1 - Campus de Beaulieu CS 74205, FR-35042 Rennes cedex - stephan.hinguant@inrap.fr 